\title{
Sugarcane bagasse performance in copper adsorption of pot still cachaça
}

\section{Desempenho do bagaço de cana-de-açúcar na adsorção de cobre em cachaça de alambique}

\author{
Ana Maria de Resende MACHADO풀 Maria das Graças CARDOSO ${ }^{3}$; Felipe Cimino DUARTE²; \\ Jeancarlo Pereira dos ANJOS ${ }^{3}$; Lidiany Mendonça ZACARONI ${ }^{3}$; Wilder Douglas SANTIAGO ${ }^{3}$
}

${ }^{1}$ Departamento de Ciência dos Alimentos, Universidade Federal de Lavras, CP 3037, 37200-000 Lavras-MG, Brasil. anamrmachado@deii.cefetmg.br

${ }^{2}$ Centro Federal de Educação Tecnológica de Minas Gerais. Av. Amazonas 5253 - Nova Suiça - Belo Horizonte - MG Brasil CEP: $30.421-169$

${ }^{3}$ Departamento de Química, Universidade Federal de Lavras, CP 3037, 37200-000 Lavras-MG, Brasil

Recebido em: 17-09-2014; Aceito em: 03-11-2015

\begin{abstract}
Pot still cachaça, which is a typical drink from Brazil, has been highlighted in the economy of Minas Gerais State, reaching the international spirit market. Cachaça is produced through sugarcane broth fermentation and is distilled in copper stills, which may sometimes cause metal contamination due to copper toxicity in high levels. Various adsorbents have already been used to reduce copper concentration, but these absorbents remove other important compounds besides copper, interfering in the sensory quality of the beverage. In search for new adsorbents, sugarcane bagasse was used with amount, size and pretreatment variations. The main result was that sugarcane bagasse, in the particle size range of 36-65 mesh, with $10 \mathrm{~g} \mathrm{~L}^{-1}$ concentration and 3 hours of contact with cachaça was efficient to remove $68 \%$ copper. Thus, sugarcane bagasse can be considered promising to reduce copper concentration during pot still cachaça production.
\end{abstract}

Additional keywords: alcoholic beverage; chemical contaminant; chemical element; natural adsorbent.

\begin{abstract}
Resumo
A cachaça de alambique, bebida típica do Brasil, tem sido destaque na economia do Estado de Minas Gerais e vem conquistando o mercado internacional de bebidas destiladas. Esta é produzida a partir da fermentação do caldo de cana-de-açúcar e destilada em alambiques de cobre, que, por vezes, pode causar contaminação com esse metal, devido a sua toxicidade quando presente em níveis elevados. Diversos adsorventes já foram utilizados para diminuir a concentração do cobre, porém esses conseguem retirar, não só o cobre, mas também outros compostos importantes que interferem na qualidade sensorial da bebida. $\mathrm{Na}$ busca por novos adsorventes, utilizou-se o bagaço de cana-de-açúcar, variando a quantidade, o tamanho e o pré-tratamento do mesmo. Com principal resultado, o bagaço de cana-de-açúcar, na faixa granulométrica de 36-65 mesh, na concentração de $10 \mathrm{~g} \mathrm{~L}^{-1}$, com 3 horas de contato com a cachaça, foi eficiente na remoção de $68 \%$ de cobre e pode ser considerado promissor para a redução da concentração deste elemento químico durante a produção de cachaça de alambique.
\end{abstract}

Palavras-chave adicionais: adsorvente natural; bebida alcoólica; contaminante químico; elemento químico.

\section{Introduction}

Cachaça is produced in copper stills, which may contaminate the beverage when production management is inadequate. Cachaça contamination occurs as a result of verdigris accumulation on the walls of distillers, which is dragged by steam during the distillation stage. Copper excess in the human body (hypercupri) may be toxic due to copper affinity with $\mathrm{S}-\mathrm{H}$ groups of many proteins and enzymes, causing diseases such as epilepsy, melanomas, rheumatoid arthritis and psychiatric diseases (Azevedo et al., 2003). Thus, materials that can adsorb copper without interfering in beverage quality are sought.

The most used natural materials in effluent metals adsorption include lignocellulosic materials, such as sugarcane bagasse, coconut shells, rice, peanuts and others. Lignocellulosic materials basically consist of lignin, cellulose, hemicellulose, extractives and proteins that have adsorptive sites, such as carbonyl, carboxyl, amino and hydroxyl groups, which are capable of removing metals by ion exchange and complexation. Typically, these materials are considered as agro-industrial residues, representing an environmental problem (Albertini et al., 2007).

Sugarcane bagasse has been used as adsorbent material for the recovery of wastewater contaminated with heavy metals, such as in cadmium, nickel, copper and zinc adsorption in wastewater from agribusiness and mining and 
metallurgical industries (De Matos et al., 2003; Grupta et al., 2003; Grupta \& Ali, 2004). This material is an agricultural residue obtained in large quantities in Brazil, consisting of four fractions, namely: $45 \%$ fiber, $2-3 \%$ insoluble solids, $2-3 \%$ soluble solids and $50 \%$ water. The fiber or bagasse is a complex material, mainly composed of cellulose (41\%), hemicellulose (25\%) and lignin (20\%) (Santos et al., 2007; Silva et al., 2007).

Research conducted with sugarcane bagasse on metal adsorption in various matrices indicate its great potential, which led this study to propose its use as adsorbent material in copper $(\mathrm{Cu})$ excess removal of cachaça produced in stills. Thus, besides using an intrinsic residue of the beverage manufacturing process, value is added to the process due to the better use of this inexpensive material. Cachaça contamination with this metal occurs during the distillation step, through the use of pot stills made of copper. Copper presence is desirable in the beverage to give pleasant sensorial characteristics, as the copper catalyses oxidation reactions of sulfur compounds produced during fermentation. However, due to its toxicity, cachaça copper content must be controlled, and the limit established by law is of $5.0 \mathrm{mg} \mathrm{L}^{-1}$ (Brasil, 2005; Cardoso et al., 2012). Therefore, several studies show that copper excess in homemade cachaça is still a barrier to its commercialization (Labanca et al., 2006; Miranda et al., 2007; Cardoso, 2013).

Cachaça copper control is done through distiller cleaning, in order to remove the verdigris. However, Brazilian cachaças still have copper contents above $2.0 \mathrm{mg} \mathrm{L}^{-1}$, which is the limit required for export (Brasil, 2005). Thus, it is necessary to develop a technology capable of reducing the copper content without significantly changing the organic, mineral and sensorial profile of beverages (Cardoso, 2013).

The most used adsorbents in cachaça copper control are activated carbon and ion exchange resin (Kunigk et al., 2011). Economically, they are one of the most feasible ways to remove copper excess from cachaça. However, other substances are adsorbed during the copper removal process, compromising the sensory quality of the beverage. Until now, all adsorbents used in cachaça copper removal caused changes in the beverage chemical composition (Cantanhede et al., 2005; Lima et al., 2006; Cantão et al., 2010). Thus, in order to find a selective adsorbent for cachaça copper removal that would not alter its composition, this study is aimed at testing sugarcane bagasse use as a copper natural adsorbent in pot still cachaça.

\section{Material and Methods}

\section{Sugarcane bagasse preparation}

The sugarcane bagasse used as adsorbent was obtained through grinding of a SP-79-1011 sugarcane cultivar, after it was cut from a third-ratoon sugarcane crop used in still cachaça production, in a distillery located in the metropolitan region of Belo Horizonte, MG. Afterwards, this material was crushed in a Nogueira (EM 9) ensiling machine, and then milled in a ball mill (Analysenmuhle A10, Quimis, Belo Horizonte). Subsequently, the material was subjected to particle size separation using a set of four Tyler sieves with $20(0.840 \mathrm{~mm}), 35(0.425 \mathrm{~mm})$, $65(0.212 \mathrm{~mm})$ and $100 \mathrm{mesh}(0.149 \mathrm{~mm})$. According to their size, particles were classified into particle sizes of $-0.840+0.425 ;-0.425+0.212 ;-0.212+0.149$ and $0.149 \mathrm{~mm}$.

Some of these materials were subjected to distilled water washing (pretreatment 1), another portion was washed with boiling water (pretreatment 2 ), and a third portion was washed with $0.01 \mathrm{~mol} \mathrm{~L}^{-1}$ sodium hydroxide solution (pretreatment 3 ), with oven drying at $70^{\circ} \mathrm{C}$ for $24 \mathrm{~h}$ afterwards. The alkali pretreatment procedure consisted of immersing the bagasse previously washed with distilled water in a $0.01 \mathrm{~mol} \mathrm{~L}^{-1}$ sodium hydroxide solution for 10 minutes. Subsequently, base excess removal was conducted through successive washes with distilled water until neutral $\mathrm{pH}$ and drying in an oven. After drying, biomass was packed in polyethylene flasks with lids (Joseph et al., 2000)

The bagasse was subjected to moisture and ash analysis. Moisture and ash contents were determined according to the rules established by IAL (2008).

\section{Preparation of cachaça enriched with copper}

The still cachaça used in the experiment was collected from the same distillery where the bagasse was acquired. The cachaça was left to rest in a small copper equipment (laboratory still) for 18 hours. Cachaça contamination by copper occurs due to verdigris presence (basic copper carbonate) $\left[\mathrm{CuCO}_{3} \mathrm{Cu}(\mathrm{OH})_{2}\right]$, which is formed on the inner walls of the equipment and is solubilized by the acid vapors of cachaça components. Copper concentrations were determined by atomic absorption spectrophotometry in a flame spectrophotometer (GBC, 932 AA model, Belo Horizonte, Brazil), based on the calibration curve in concentration ranges from 1.0 to $5,0 \mathrm{mg} \mathrm{L}^{-1}$ copper. Cachaças with a concentration above $5.0 \mathrm{mg} \mathrm{L}^{-1}$ were diluted in $40 \%$ alcohol solution (v/v).

\section{Adsorbent amount study}

The effect of adsorbent amount in cachaça copper removal was found, under magnetic stirring, at room temperature $\left(\sim 25^{\circ} \mathrm{C}\right)$ for $3 \mathrm{~h}$, in the concentrations of $2.5,5.0,10$ and $20 \mathrm{~g} \mathrm{~L}^{-1}$. $50 \mathrm{~mL}$ of cachaça containing $15.03 \mathrm{mg} \mathrm{L}^{-1}$ copper was added to each adsorbent concentration. The bagasse used in this experiment was subjected to pretreatment 1 (washed with distilled water). After stirring was final- 
ized, mixtures were filtered by simple filtration and residual copper concentrations were determined.

\section{Particle size effect}

Bagasse adsorption behavior was evaluated in a second experiment using four bagasse particle sizes, 20-35, 36-65, 66-100 and 101 mesh, using the bagasse from pretreatment 1 in the periods of 30,90 and 180 minutes of contact, at room temperature $\left(\sim 25^{\circ} \mathrm{C}\right)$ and under stirring. In each case, $0.5 \mathrm{~g}$ bagasse was added to $50 \mathrm{~mL}$ of cachaça with a concentration of $15.03 \mathrm{mg} \mathrm{L}^{-1}$ copper. After the respective contact periods between adsorbent material and cachaça, the residue was separated by simple filtration and copper residual concentrations were determined by atomic absorption spectrophotometry.

\section{Bagasse treatment effect study}

In order to evaluate bagasse behavior after previous treatment, three $2.0 \mathrm{~L}$ volumetric flask series containing $10 \mathrm{~g}$ of adsorbent with particle size range of 36-65 mesh and $1.0 \mathrm{~L}$ of cachaça with $2.53 \mathrm{~g} \mathrm{~L}^{-1}$ copper concentration were set and stirred for 180 minutes. Each series contained the adsorbents for each pretreatment, in triplicate. Thus, the means of each series and the final mean of each pretreatment were obtained.

\section{Study of bagasse effect on congener adsorption}

In this procedure, two different cachaças were used, as follows: Cachaça $A$, enriched with three different copper concentrations, and the freshly distilled cachaça $B$, without copper enrichment. The experiments were conducted in triplicate and kept under stirring at room temperature $\left(\sim 25^{\circ} \mathrm{C}\right)$ for 180 minutes. Volumetric flasks containing $10 \mathrm{~g}$ of 36-65 mesh adsorbent treated with hot water and $1.0 \mathrm{~L}$ of cachaça with the copper concentrations in parenthesis (Cachaça A with 2.52, 7.67 and $12.65 \mathrm{mg} \mathrm{L}^{-1}$ and cachaça $B$ with $6.46 \mathrm{mg} \mathrm{L}^{-1}$ ) were used. After simple filtration, a part of each sample was subjected to analysis of copper, volatile acidity and dry extract, and the remainder was subjected to simple distillation, in order to determine esters, methanol, aldehydes, higher alcohols, furfural and alcohol content. These analyzes were conducted according to the specifications established by the Ministry of Agriculture, Livestock and Supply (MAPA), Brasil (2005).

The adsorbed $\mathrm{Cu}^{2+}(\%)$ ion retention rate was calculated by the difference between the initial concentration and the metal residual concentration in the beverage after adsorption.

\section{Statistical analysis}

A completely randomized design (CRD) with three repetitions was used for the experiment. In order to obtain the adsorbent concentration effect in each particle size range, data were evaluated in a $5 \times 4$ factorial (adsorbent concentrations $\times$ particle sizes). In order to obtain the adsorbent treatment effect (35-66 mesh) in copper removal in 180 minutes and to conduct physicochemical analysis in each sample class, data were subjected to analysis of variance (ANOVA), and means were compared by Scott-Knott test at $95 \%$ confidence level, using the SISVAR statistical program (Ferreira, 2007).

\section{Results and discussions}

The moisture content found in bagasse subjected to the three pretreatments (washed with distilled water -1 , with hot water - 2 , and treated with alkali - 3) was not significantly different from each other, not even in different particle sizes. Thus, values found for bagasse pretreated with hot water were of $3.49 \pm 0.24 \%$ in the $36-65$ mesh range and of $3.42 \pm 0.21 \%$ in the $66-100$ mesh range. Likewise, the ash content found for the different particle size ranges of the bagasse treated with hot water was of $2.1 \pm 0.26 \%$ for $36-65$ mesh, $1.97 \pm 0.31 \%$ for $66-100$ mesh and $2.01 \pm 0.34 \%$ for 101 mesh. These values corroborate those found by Pandey et al. (2000) and Singh et al. (2007), who determined an ash content of 2.4 and $2.3 \%$, respectively, for the bagasse. The low ash content of bagasse compared to other residues, such as rice and wheat straw, having 17.5 and $11.0 \%$, respectively, has advantages in metal adsorption, as it prevents the desorption of the metal from the adsorbent material to the solution.

Final cachaça copper concentrations with adsorbent amount and particle size variations and in the stirring time of 3 hours are shown in Table 1. It was observed that the highest adsorbent amount resulted in a lower metal residual concentration (up to a $10 \mathrm{~g} \mathrm{~L}^{-1}$ adsorbent concentration). There was adsorption decrease afterwards, as shown in the highest copper final concentration. Adsorption increase according to adsorbent amount can be attributed to higher adsorptive site availability in the bagasse. The most effective copper adsorption occurred in the concentration of $10 \mathrm{~g} \mathrm{~L}^{-1}$ adsorbent, in all particle size ranges. In concentrations that were lower than $5 \mathrm{~g} \mathrm{~L}^{-1}$, the adsorbent surface becomes saturated by the metal, and the residual copper concentration in the beverage is higher. In concentrations that are higher than $10 \mathrm{~g} \mathrm{~L}^{-1}$ adsorbent, lower copper removal occurs, especially in the adsorbent with the smallest particle size. This is probably related to the difficult stirring, caused by the large bagasse volume in the solution.

The analysis of variance of results showed significant differences between copper residual concentrations for almost all treatments, except for cachaça and control, showing that there was no copper concentration change in the beverage during magnetic stirring. Adsorbent amount and its particle size influenced the copper adsorption process in the beverage $(p<0.05)$. The bagasse, in particle sizes of 20-35 mesh and adsorbent concentrations of $20 \mathrm{~g} \mathrm{~L}^{-1}, 36-65$ mesh and $10 \mathrm{~g} \mathrm{~L}^{-1}$, and 101 mesh 
and $5 \mathrm{~g} \mathrm{~L}^{-1}$, showed the same efficiency in copper removal. In addition, 101 mesh adsorbents in the concentration of $20 \mathrm{~g} \mathrm{~L}^{-1}$ and 20-35 mesh and 36-65 mesh adsorbents in the concentration of $5 \mathrm{~g} \mathrm{~L}^{-1}$ showed the same behavior, showing that adsorbent size defines its concentration and adsorbing capacity, which in turn is related to the contact surface.

Table 1 - Final copper concentration $\left(\mathrm{mg} \mathrm{L}^{-1}\right)$ after bagasse treatment with different adsorbent amounts and particle sizes, $3 \mathrm{~h}$ of contact and $15.03 \mathrm{mg} \mathrm{L}^{-1}$ copper in cachaça.

\begin{tabular}{|c|c|c|c|c|}
\hline \multirow{3}{*}{$\begin{array}{l}\text { Adsorbent concentration } \\
\qquad\left(\mathrm{g} \mathrm{L}^{-1}\right)\end{array}$} & \multicolumn{4}{|c|}{ Particle size ranges (mesh) } \\
\hline & $20-35$ & $36-65$ & $66-100$ & 101 \\
\hline & \multicolumn{4}{|c|}{ Copper residual concentration (mg L-1) } \\
\hline Control & \multicolumn{4}{|c|}{$14.97 \mathrm{aA}$} \\
\hline Cachaça & \multicolumn{4}{|c|}{$15.03 \mathrm{aA}$} \\
\hline 2.5 & $10.21 \pm 0.16 \mathrm{bB}$ & $9.05 \pm 0.21 \mathrm{bD}$ & $8.54 \pm 0.19 \mathrm{bE}$ & $9.47 \pm 0.24 \mathrm{bC}$ \\
\hline 5.0 & $6.65 \pm 0.32 \mathrm{cB}$ & $6.41 \pm 0.28 \mathrm{cB}$ & $5.50 \pm 0.25 \mathrm{cC}$ & $5.71 \pm 0.27 \mathrm{dC}$ \\
\hline 10.0 & $5.30 \pm 0.23 \mathrm{eB}$ & $4.73 \pm 0.32 \mathrm{dC}$ & $3.72 \pm 0.23 \mathrm{eD}$ & $4.54 \pm 0.19 \mathrm{eC}$ \\
\hline 20.0 & $5.91 \pm 0.12 \mathrm{dC}$ & $4.78 \pm 0.23 \mathrm{dD}$ & $4.31 \pm 0.27 \mathrm{dE}$ & $6.56 \pm 0.32 \mathrm{cB}$ \\
\hline
\end{tabular}

${ }^{*}$ Mean \pm standard deviation; Means followed by the same lowercase letter in the columns and the same capital letter in the lines do not differ by Scott-Knott test $(\alpha=5 \%)$

The smallest particle (101) supports a large adsorbent amount, while the largest particle (20-35) must have a lower adsorbent amount to have the same response in copper adsorption.

Copper removal percentages by the adsorbent are shown in Figure 1. The 66-100 mesh bagasse was the most efficient in copper adsorption, in all adsorbent concentrations. However, it showed the highest copper retention rate $(75 \%)$ in the $10 \mathrm{~g} \mathrm{~L}^{-1}$ adsorbent concentration. Afterwards, with the same particle size and higher adsorbent concentration, there was a significant removal of $73 \%$. In larger particle sizes, there was removal decrease. The lowest removal rates, below $43 \%$, occurred in the lowest adsorbent concentration.

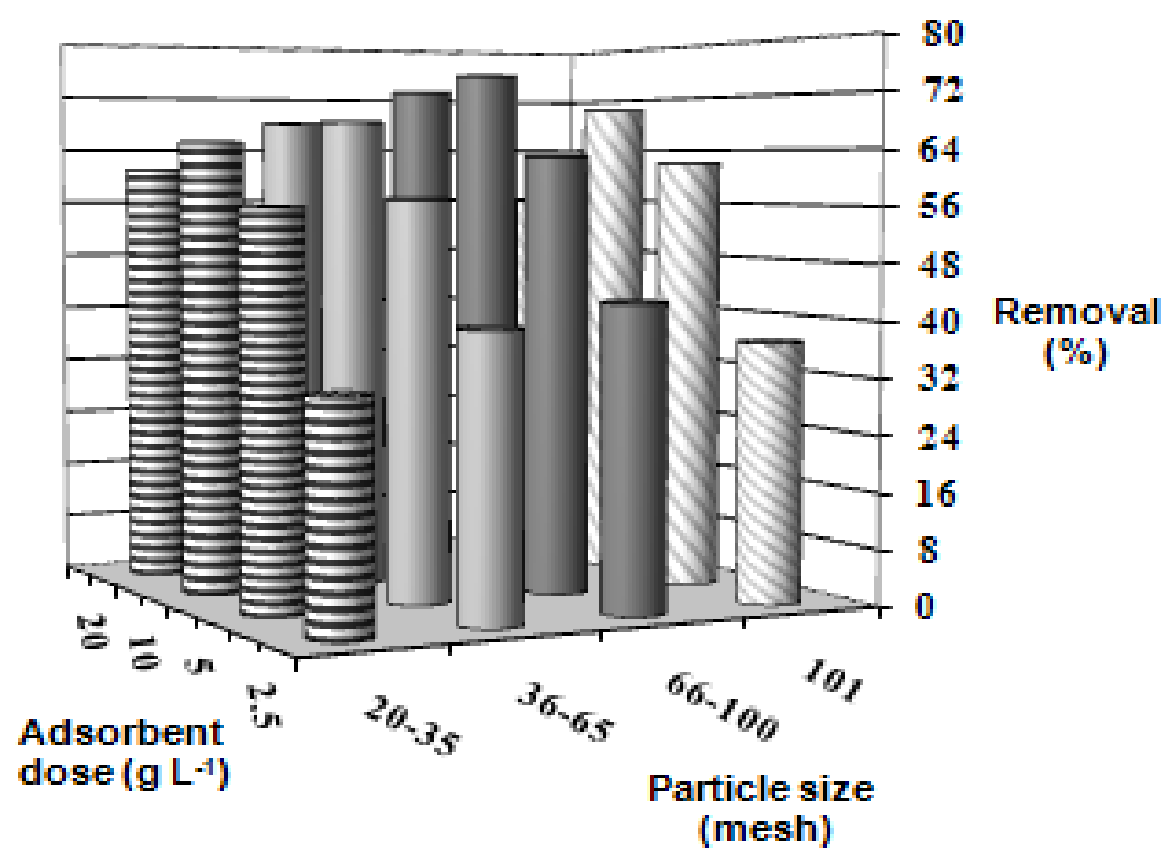

Figure 1 - Copper retention rate (\%) in the different particle sizes and adsorbent amount. 
The intermediate particle size, 36-65 mesh, also proved effective in copper removal, since there was $68 \%$ removal in the two highest adsorbent concentrations.

The 3 hours contact time is too long to be implemented in a routine situation. Thus, the subsequent study was based on the best conditions found regarding adsorbent amount and contact time variations. Although the two intermediate particle sizes were more effective in copper removal, the four adsorbent sizes were tested again.

In Figure 2, the copper ion adsorption behavior by the bagasse can be observed in the different contact times and particle sizes. It was observed that the adsorbent was effective for cachaça copper removal, as there was metal removal in the various particle sizes and in the three contact times when compared with the starting cachaça, which had a $15.03 \mathrm{mg} \mathrm{L}^{-1}$ copper content. It has been found that adsorption varies according to particle size and contact time. With regard to contact time, copper adsorbed amount increases were observed when the time changed from 30 to 180 minutes. The particle sizes used showed significant differences in copper removal, where the smaller the particle, the higher the copper removal percentage, except for the 101 mesh particle size. Maximum copper removal occurred with the 66-100 mesh bagasse in time of 180 minutes. Decreased copper removal percentage with the 20-35 mesh bagasse in the time of 30 minutes was attributed to insufficient contact time and lower adsorptive site amount on this particle. No copper concentration change occurred when cachaça was compared to the control, as shown in Figure 2. The four treatments showed lower copper removal in the 30 minutes contact time, as they showed a higher copper residual concentration, indicating that contact time was insufficient for the metal to be adsorbed by the bagasse. For the smallest particle (101 mesh), a slight decrease in copper ion removal in relation to the 66-100 mesh bagasse in the assessed time periods was observed. This behavior had already been observed when the adsorbent was evaluated in the contact time of 3 hours.

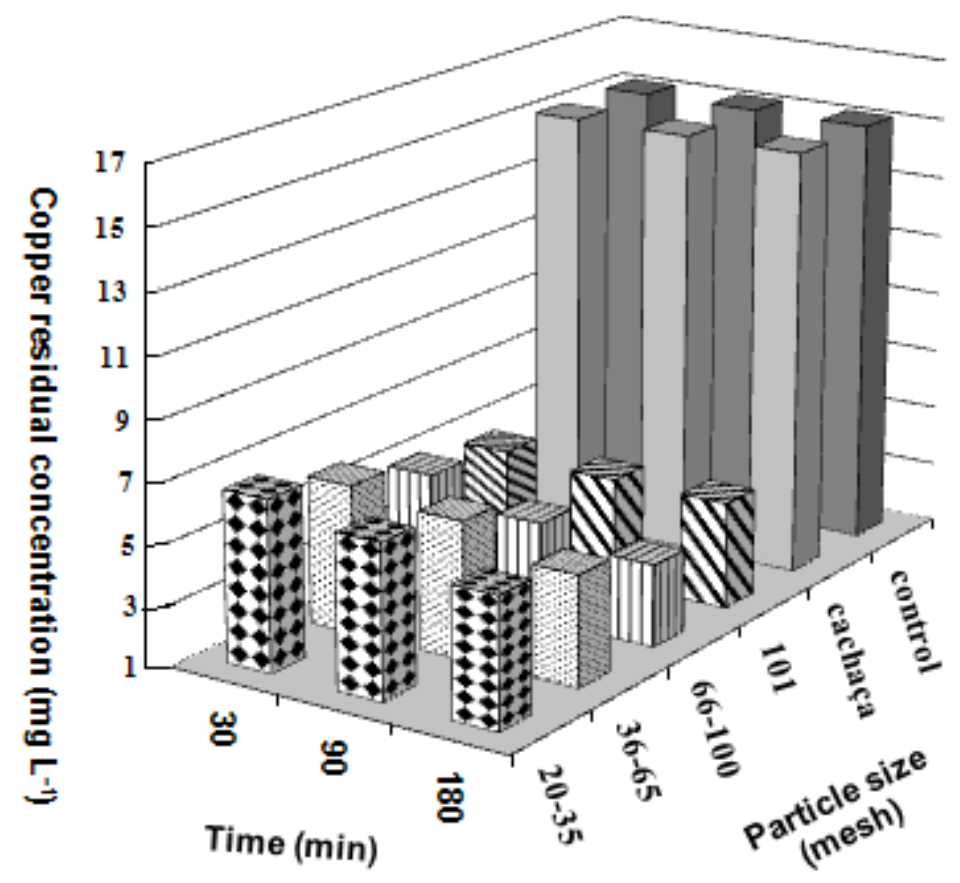

Figure 2 - Copper residual concentration after adsorption by sugarcane bagasse with 1:100 adsorbent/cachaça ratio in cachaça with $15.03 \mathrm{mg} \mathrm{L}^{-1}$ copper.

These results are similar to those found by Karnitz et al. (2007), who showed the efficiency of the chemically modified bagasse in particle sizes of $10,30,45$ and 60 mesh for copper, cadmium and lead ions adsorption in aqueous solutions.

Regarding the bagasse particle size used in metal adsorption, research showed a quite wide variation, with particle sizes above and below those used in this study. Particles with intermediate size (36-65 mesh) were selected for further studies due to their efficient absorption and ease of preparation and operation, besides not interfering in the bever- age color. The particle size choice comes against future studies using bagasse in cachaça copper removal with a continuous system (fixed bed). In this system, small particles are not suitable, as they may cause high flow resistance due to increased packaging and decreased permeability of particles in the bed. As a result, balance between the particle size and removal percentage should be sought to a continuous adsorption system. As the 36-65 mesh particle has an intermediate removal percentage, this size may be employed.

Regarding pretreatments, the adsorption 
obtained with these materials can be observed on Table 2.

The bagasse washed with distilled water absorbed the copper from the beverage, but changed its color, leaving it slightly yellowish. This interference was observed the bagasse treated in hot water and/or with sodium hydroxide solution was used. Data in Table 2 show copper adsorption efficiency by the bagasse in the three treatments. Treatment 1 showed $50 \%$ copper removal from the beverage. However, the removed copper amount increased in bagasse from treatment 2 and 3. The 36-65 mesh bagasse treated with $\mathrm{NaOH} 0.01 \mathrm{~mol} \mathrm{~L}^{-1}$ was the most efficient, as it removed $75 \%$ copper from the cachaça. A similar behavior was observed with the bagasse in the range of 66-100 mesh, which was simply washed with distilled water, as shown in Figure 1.

Table 2 - Adsorbent treatment (35-66 mesh) effect in copper removal within 180 minutes.

\begin{tabular}{cccc}
\hline Treatments & $\begin{array}{c}{ }^{(1)} \text { Residual copper } \\
\left(\mathrm{mg} \mathrm{L}^{-1}\right)\end{array}$ & $\begin{array}{c}(2) \mathrm{RSD} \\
(\%)\end{array}$ & $\begin{array}{c}\text { Removal } \\
(\%)\end{array}$ \\
\hline 1 & $1.25 \pm 0.25 \mathrm{~b}$ & 4.00 & 51 \\
2 & $0.73 \pm 0.02 \mathrm{c}$ & 1.37 & 71 \\
3 & $0.63 \pm 0.03 \mathrm{~d}$ & 4.76 & 75 \\
Control & $2.53 \pm 0.04 \mathrm{a}$ & 1.57 & - \\
Cachaça & $2.52 \pm 0.06 \mathrm{a}$ & 2.38 & - \\
\hline
\end{tabular}

(1) Mean \pm standard deviation; Means followed by the same lowercase letter in the columns and the same capital letter in the lines do not differ by Scott-Knott test $(\alpha=5 \%)$; ${ }^{(2)} \mathrm{RSD}$ - relative standard deviation

The sodium hydroxide bagasse pretreatment led to better copper removal from the beverage. During the treatment with a basic solution, hydroxyl groups $(\mathrm{OH})$ reacted with sodium hydroxide, resulting in sodium cellulose, as shown in equation 1 . The increased metal removal rate can be explained by the increased contact surface, in addition to sodium cellulose presence, which facilitates copper adsorption due to electrostatic attraction (Karnitz et al., 2007)

Fiber-OH $+\mathrm{NaOH} \rightarrow$ Fiber $-\mathrm{O}^{-} \mathrm{Na}^{+}+\mathrm{H}_{2} \mathrm{O}$

The bagasse treatment with sodium hydroxide led to low fiber matter loss due to hemicellulose and lignin dissolution, which are soluble in basic solution, making the fibers thinner, dispersed and with a rough surface (Ray et al., 2001).

It was observed that there was no big difference in copper residual concentration between the bagasse pretreatment with sodium hydroxide solution and the bagasse pretreatment with hot water. This is relevant to be emphasized as it is an economically important fact due to reduced costs.

Results obtained from cachaça treatments with sugarcane bagasse are shown in Table 3 . Parameters analyzed for cachaça A, except for those enriched with copper, were within the limits established by the Ministry of Agriculture, Livestock and Supply (MAPA). For cachaça B, only the copper was above the law.
Cachaça A bagasse adsorption process did not lead to any alcohol or aldehyde content change. For volatile acidity, a minor increase was observed. However, ethanol oxidation into acetic acid can be used, increasing acidity. Higher alcohols, esters, furfural and methanol concentrations suffered a minor reduction, as these substances were probably adsorbed by the bagasse. Data in Table 3 show that there was no beverage secondary components evaporation during stirring, as the "control" sample did not vary in their concentration, compared to the starting cachaça.

Regarding the dry extract, concentration increase was observed after bagasse adsorption. This may have happened due to bagasse components dissolution in the beverage. Comparison between treated cachaça, starting cachaça and control means showed differences. The bagasse adsorption process with different copper concentrations showed a very high removal percentage. The starting cachaça, with $2.52 \mathrm{mg} \mathrm{L}^{-1}$ copper, decreased the copper content to $0.73 \mathrm{mg} \mathrm{L}^{-1}$ (71\% removal) after adsorption. For the cachaça with the highest copper concentration, $12.57 \mathrm{mg} \mathrm{L}^{-1}$, there was removal percentage reduction $(65 \%)$, and the same occurred for the intermediate concentration, $7.67 \mathrm{mg} \mathrm{L}^{-1}$. In relation to copper, there was mean significant difference for all cachaça samples compared to the respective samples treated with sugarcane bagasse.

Cachaça B showed lower alcohol content, volatile acidity, aldehydes, esters, methanol and furfural values compared to cachaça $A$ before bagasse treatment, although showing increased higher alcohol values. It is common to have lower ester concentrations in freshly distilled cachaças. Cachaça B had a very low esters concentration. For the same bagasse adsorption process, cachaça $B$ showed similar behavior to that of cachaça $A$, with a slight decrease in higher alcohol, ester and furfural concentrations. However, esters alteration was very significant, which did not occur with cachaça $A$.

On the other hand, there was acidity reduction. In cachaça B, there was $75 \%$ copper removal. Cachaça treatment with sugarcane bagasse showed no mean difference for alcohol content, volatile acidity, aldehydes and methanol in all samples. Sample treatment comparison showed differences between means for higher alcohols, furfural and esters. Sugarcane bagasse efficiently removed cachaça copper in different concentrations. In cachaça $A$, there was a slight change in secondary components. However, in cachaça $B$, in which the esters concentration was already quite low after bagasse treatment, there was a significant decrease of this parameter. In addition, there was a slight higher alcohol concentration increase in cachaça $B$, with high higher alcohol content (300.92 mg/100 mL anhydrous alcohol), although below the established limit. Thus, it can be inferred that the sugarcane bagasse is effective in cachaça copper removal in different metal concentrations. However, it 
is desirable to the beverage to be matured, so that secondary components are in a balanced concentra-

tion and not suffering significant changes, not compromising the beverage sensory quality.

Table $3-{ }^{(1)}$ Results of alcohol content (AC), in $\% \mathrm{v} / \mathrm{v}$ at $20^{\circ} \mathrm{C}$, volatile acidity (VA), aldehyde (AL), higher alcohol (HA), furfural $(F)$, esters $(E)$, methanol $(M)$, in $\mathrm{mg} / 100 \mathrm{~mL}$ anhydrous alcohol, copper $(\mathrm{C})$, in $\mathrm{mg} \mathrm{L}^{-1}$, and dry extract $(D E)$, in $\mathrm{g} \mathrm{L}^{-1}$, in cachaça treated with sugarcane bagasse.

\begin{tabular}{|c|c|c|c|c|c|c|c|c|c|}
\hline Sample & $A C$ & VA & AL & $\mathrm{HA}$ & $\mathrm{F}$ & $E$ & $M$ & C & $\mathrm{DE}$ \\
\hline $\begin{array}{l}\text { Cachaça } \\
\left(2.52 \mathrm{mg} \mathrm{L}^{-1}\right)\end{array}$ & $\begin{array}{l}42.82 \mathrm{a} \\
\pm 0.22\end{array}$ & $\begin{array}{c}147.12 \mathrm{a} \\
\pm 2.18\end{array}$ & $\begin{array}{l}18.60 \mathrm{a} \\
\pm 0.28\end{array}$ & $\begin{array}{c}187.04 \mathrm{a} \\
\pm 2.14\end{array}$ & $\begin{aligned} & 0.52 \mathrm{a} \\
\pm & 0.03\end{aligned}$ & $\begin{array}{l}67.81 \mathrm{a} \\
\pm 1.54\end{array}$ & $\begin{array}{l}15.13 \mathrm{a} \\
\pm 1.43\end{array}$ & $\begin{aligned} & 2.52 \mathrm{a} \\
\pm & 0.06\end{aligned}$ & $\begin{aligned} & 0.14 b \\
\pm & 0.01\end{aligned}$ \\
\hline Control & $\begin{array}{l}42.72 \mathrm{a} \\
\pm 0.20\end{array}$ & $\begin{array}{c}147.01 \mathrm{a} \\
\pm 2.01\end{array}$ & $\begin{array}{l}18.57 \mathrm{a} \\
\pm 0.21\end{array}$ & $\begin{array}{c}186.16 \mathrm{a} \\
\pm 2.01\end{array}$ & $\begin{array}{c}0.50 \mathrm{a} \\
\pm 0.01\end{array}$ & $\begin{array}{l}66.78 \mathrm{a} \\
\pm 1.48\end{array}$ & $\begin{array}{l}15.01 \mathrm{a} \\
\pm 1.38\end{array}$ & $\begin{aligned} & 2.50 \mathrm{a} \\
\pm & 0.04\end{aligned}$ & $\begin{aligned} & 0.12 b \\
\pm & 0.01\end{aligned}$ \\
\hline $\begin{array}{l}\text { Cachaça A } \\
\text { treated }\end{array}$ & $\begin{array}{l}42.50 \mathrm{a} \\
\pm 0.16\end{array}$ & $\begin{array}{c}150.18 \mathrm{a} \\
\pm 1.14\end{array}$ & $\begin{array}{l}18.57 \mathrm{a} \\
\pm 0.12\end{array}$ & $\begin{array}{c}178.32 \mathrm{~b} \\
\pm 2.58\end{array}$ & $\begin{array}{l}0.45 \mathrm{~b} \\
\pm 0.02\end{array}$ & $\begin{array}{l}65.53 \mathrm{a} \\
\pm 1.07\end{array}$ & $\begin{array}{l}13.83 \mathrm{a} \\
\pm 0.92\end{array}$ & $\begin{array}{l}0.73 \mathrm{~b} \\
\pm 0.02\end{array}$ & $\begin{aligned} & 0.21 \mathrm{a} \\
\pm & 0.05\end{aligned}$ \\
\hline $\begin{array}{l}\text { Cachaça A } \\
\left(12.56 \mathrm{mg} \mathrm{L}^{-1}\right)\end{array}$ & $\begin{array}{l}42.81 \mathrm{a} \\
\pm 0.21\end{array}$ & $\begin{array}{c}149.38 \mathrm{a} \\
\pm 0.56\end{array}$ & $\begin{array}{l}18.62 \mathrm{a} \\
\pm 0.15\end{array}$ & $\begin{array}{c}187.18 \mathrm{a} \\
\pm 2.42\end{array}$ & $\begin{aligned} & 0.51 \mathrm{a} \\
\pm & 0.02\end{aligned}$ & $\begin{array}{l}67.14 \mathrm{a} \\
\pm 1.42\end{array}$ & $\begin{array}{l}15.06 \mathrm{a} \\
\pm 1.38\end{array}$ & $\begin{array}{l}12.56 \mathrm{a} \\
\pm 0.42\end{array}$ & $\begin{array}{l}0.14 \mathrm{~b} \\
\pm 0.02\end{array}$ \\
\hline Control & $\begin{array}{l}42.97 \mathrm{a} \\
\pm 0.05 \mathrm{a}\end{array}$ & $\begin{array}{c}150.08 \mathrm{a} \\
\pm 1.87\end{array}$ & $\begin{array}{l}18.60 \mathrm{a} \\
\pm 0.14\end{array}$ & $\begin{array}{c}186.96 \mathrm{a} \\
\pm 1.64\end{array}$ & $\begin{array}{l}0.51 \mathrm{a} \\
\pm 0.03\end{array}$ & $\begin{array}{l}66.12 \mathrm{a} \\
\pm 2.08\end{array}$ & $\begin{array}{l}15.06 \mathrm{a} \\
\pm 1.28\end{array}$ & $\begin{array}{l}12.53 \mathrm{a} \\
\pm 0.54\end{array}$ & $\begin{array}{l}0.13 \mathrm{~b} \\
\pm 0.02\end{array}$ \\
\hline $\begin{array}{l}\text { Cachaça A } \\
\text { treated }\end{array}$ & $\begin{array}{l}42.79 a \\
\pm 0.15\end{array}$ & $\begin{array}{c}150.87 \mathrm{a} \\
\pm 1.25\end{array}$ & $\begin{array}{l}18.40 \mathrm{a} \\
\pm 0.21\end{array}$ & $\begin{array}{c}177.77 \text { b } \\
\pm 1.31\end{array}$ & $\begin{array}{c}0.50 \mathrm{a} \\
\pm 0.01\end{array}$ & & $\begin{array}{l}13.87 \mathrm{a} \\
\pm 0.86\end{array}$ & $\begin{array}{r}4.50 \mathrm{~b} \\
\pm 0.04\end{array}$ & $\begin{array}{r}0.25 \mathrm{a} \\
\pm 0.04\end{array}$ \\
\hline $\begin{array}{l}\text { Cachaça A } \\
\left(7.67 \mathrm{mg} \mathrm{L}^{-1}\right)\end{array}$ & $\begin{array}{l}42.81 \mathrm{a} \\
\pm 0.21\end{array}$ & $\begin{array}{c}149.92 \mathrm{a} \\
\pm 0.60\end{array}$ & $\begin{array}{l}18.61 \mathrm{a} \\
\pm 0.16\end{array}$ & $\begin{array}{c}187.49 \mathrm{a} \\
\pm 2.02\end{array}$ & $\begin{array}{r}0.51 \mathrm{a} \\
\pm 0.03\end{array}$ & $\begin{array}{l}67.13 \mathrm{a} \\
\pm 0.87\end{array}$ & $\begin{array}{l}14.55 a \\
\pm 0.48\end{array}$ & $\begin{array}{l}7.67 \mathrm{a} \\
\pm 0.12\end{array}$ & $\begin{aligned} & 0.14 \mathrm{~b} \\
\pm & 0.01\end{aligned}$ \\
\hline Control & $\begin{array}{l}42.97 \mathrm{a} \\
\pm 0.05\end{array}$ & $\begin{array}{c}150.08 \mathrm{a} \\
\pm 1.87\end{array}$ & $\begin{array}{l}18.60 \mathrm{a} \\
\pm 0.14\end{array}$ & $\begin{array}{c}186.96 \mathrm{a} \\
\pm 1.64\end{array}$ & $\begin{array}{l}0.51 \mathrm{a} \\
\pm 0.03\end{array}$ & $\begin{array}{l}66.12 \mathrm{a} \\
\pm 2.08\end{array}$ & $\begin{array}{l}15.06 \mathrm{a} \\
\pm 1.43\end{array}$ & $\begin{array}{r}7.45 \mathrm{a} \\
\pm 0.54\end{array}$ & $\begin{aligned} & 0.13 b \\
\pm & 0.02\end{aligned}$ \\
\hline $\begin{array}{l}\text { Cachaça A } \\
\text { treated }\end{array}$ & $\begin{array}{l}42.57 \mathrm{a} \\
\pm 0.03\end{array}$ & $\begin{array}{c}151.73 \mathrm{a} \\
\pm 1.89\end{array}$ & $\begin{array}{l}18.47 \mathrm{a} \\
\pm 0.12\end{array}$ & $\begin{array}{c}175.88 \mathrm{~b} \\
\pm 1.51\end{array}$ & $\begin{array}{c}0.48 \text { a } \\
\pm 0.03\end{array}$ & $\begin{array}{l}57.49 \mathrm{~b} \\
\pm 1.11\end{array}$ & $\begin{array}{l}13.85 a \\
\pm 0.98\end{array}$ & $\begin{aligned} & 2.68 \mathrm{~b} \\
\pm & 0.03\end{aligned}$ & $\begin{array}{l}0.25 a \\
\pm 0.05\end{array}$ \\
\hline $\begin{array}{l}\text { Cachaça B } \\
\left(6.46 \mathrm{mg} \mathrm{L}^{-1}\right)\end{array}$ & $\begin{array}{l}39.43 \mathrm{a} \\
\pm 0.23\end{array}$ & $\begin{array}{l}29.52 \mathrm{a} \\
\pm 0.17\end{array}$ & $\begin{array}{r}8.63 \mathrm{a} \\
\pm 0.32\end{array}$ & $\begin{array}{c}301.92 \mathrm{a} \\
\pm 2.49\end{array}$ & $\begin{array}{c}0.08 \mathrm{a} \\
\pm 0.01\end{array}$ & $\begin{array}{l}13.53 \mathrm{a} \\
\pm 0.08\end{array}$ & nd & $\begin{aligned} & 6.46 \mathrm{a} \\
\pm & 0.08\end{aligned}$ & $\begin{aligned} & 0.061 \mathrm{~b} \\
\pm & 0.003\end{aligned}$ \\
\hline Control & $\begin{array}{l}39.43 \text { a } \\
\pm 0.17\end{array}$ & $\begin{array}{l}29.59 \mathrm{a} \\
\pm 0.15\end{array}$ & $\begin{array}{r}8.63 \text { a } \\
\pm 0.32\end{array}$ & $\begin{array}{c}301.71 \mathrm{a} \\
\pm 5.16\end{array}$ & $\begin{array}{c}0.08 \mathrm{a} \\
\pm 0.01\end{array}$ & $\begin{array}{l}13.52 \mathrm{a} \\
\pm 0.06\end{array}$ & nd & $\begin{array}{r}6.46 \mathrm{a} \\
\pm 0.07\end{array}$ & $\begin{aligned} & 0.061 \mathrm{~b} \\
\pm & 0.003\end{aligned}$ \\
\hline $\begin{array}{l}\text { Cachaça B } \\
\text { treated }\end{array}$ & $\begin{array}{l}38.83 \mathrm{~b} \\
\pm 0.07\end{array}$ & $\begin{array}{l}28.72 \mathrm{a} \\
\pm 1.42 \\
\end{array}$ & $\begin{array}{r}8.67 \mathrm{a} \\
\pm 0.01 \\
\end{array}$ & $\begin{array}{c}304.52 \mathrm{a} \\
\pm 6.69 \\
\end{array}$ & $\begin{array}{l}0.06 \mathrm{a} \\
\pm 0.01\end{array}$ & $\begin{aligned} & 2.29 \mathrm{~b} \\
& \pm 0.01 \\
&\end{aligned}$ & nd & $\begin{aligned} & 1.81 \mathrm{~b} \\
& \pm 0.02 \\
&\end{aligned}$ & $\begin{array}{c}0.12 \mathrm{a} \\
\pm 0.04 \\
\end{array}$ \\
\hline Limits & $38-54$ & 150.00 & 30.00 & 360.00 & 5.00 & 200.00 & 20.00 & 5.00 & 6.00 \\
\hline
\end{tabular}

(1) Means followed by the same letter in the column (compared by sample treatment) do not differ by Scott-Knott test $(\alpha=5 \%)$. nd $=$ not detected

\section{Conclusions}

Sugarcane bagasse in 36-65 and 66-100 mesh particle sizes and 10 and $20 \mathrm{~g} \mathrm{~L}^{-1}$ concentrations was effective in cachaça copper removal with varying copper concentrations and contact time of 180 minutes. Both adsorbents removed approximately $70 \%$ copper from the beverage. However, the 36-65 mesh particle size adsorbent is more suitable for this treatment, as it does not interfere in beverage color. In general, it can be said that the bagasse removes copper and does not change the beverage chemical composition. Therefore, copper adsorption results shown in this study indicate the possibility of using this material as a low cost adsorbent. Sugarcane bagasse with hot water treatment and under the study conditions removes $71 \%$ of cachaça copper. For commercial viability, more studies in continuous system should be conducted.

\section{Acknowledgments}

Thanks to the CAPES program, CNPq and FAPEMIG, for financial support. Thanks to the CEFET-MG for carrying out the analysis.

\section{References}

Albertini S, Carmo LF, Prado Filho LG (2007) Utilização de serragem e bagaço de cana-de-açúcar para adsorção de cádmio. Ciência e Tecnologia de Alimentos 27(1):113-118.

Azevedo SM, Cardoso MG, Pereira NE, Ribeiro CFS, Silva VF, Aguiar FC (2003) Levantamento da contaminação por cobre nas aguardentes de cana-de-açúcar produzidas em Minas Gerais. Ciência e Agrotecnologia 27(3):618-624. 
BRASIL. Leis, decretos, etc. Instrução Normativa no 13 de 29 de junho de 2005. Diário Oficial da União. Brasília, 30 de junho de 2005.

Cantanhede LB, Lima JB, Lopes GS, Farias RF, Bezerra CWB (2005) Uso de sílica e sílica-titânia organofuncionalizadas para a remoção de $\mathrm{Cu}$ (II) em aguardentes. Ciência e Tecnologia de Alimentos 25(3):500-505.

Cantão FO, Melo WC, Cardoso MG, Anjos JP, Oliveira LCA (2010) Avaliação e remoção de cobre em aguardentes de cana pela utilização dos aluminossilicatos: zeólita e bentonita. Ciência e Agrotencnologia 34(5):1109-1115.

Cardoso MG, Zacaroni LM, Santiago WD, Rodrigues LMA, Mendonça JGP, Duarte FC, Machado AMR, Ribeiro CFS (2012) Cachaça de Minas Gerais/Brasil: Produção e Qualidade. Agrotect-Revista Técnico Científica Agrícola 4:98-101.

Cardoso MG (2013) Análises físico-químicas e cromatográficas de aguardente. In: Cardoso MG (ed) Produção de aguardente de cana, 3 ed, Lavras: UFLA 150-187.

De Matos AT, Brandão VS, Neves JCL, Martinez MA (2003) Removal of $\mathrm{Cu}$ and $\mathrm{Zn}$ from swine raising wastewater using organic filters. Environmental Technology 24(2):171-178.

Ferreira DF (2007) SISVAR, Sistema de análise de variância versão 5.0; UFLA, Lavras.

Grupta VK, Jain CK, Ali I, Sharma M, Saine VK (2003) Removal of cadmium and nickel from wastewater using bagasse fly ash-a sugar industry waste. Water Research 37(16):4038-4044.

Grupta VK, Ali I (2004) Removal of lead and chromium from wastewater using bagasse fly ash-sugar industry waste. Journal of colloid and interface Science 271(2):321-328.

IAL - Instituto Adolfo Lutz (2008) Métodos químicos e físicos para análise de alimentos. 4. ed., São Paulo, 2008. 1020p.

Joseph KR, Mattoso LHC, Toledo RD, Thomas S, Carvalho LH, Pothen L, Kala S, James B (2000) Natural fiber reinforced thermoplastic composites. In Frollini E, Leão A, Mattoso LHC (eds.) Natural Polymers and Agrofibers Based Composites, EMBRAPA: São Carlos. p.159-201.
Karnitz Ojr, Gurgel LVA, Melo JCP, Botaro VR, Melo TMS, Gil RPF, Gil LF (2007) Adsorption of heavy metal ion from aqueous single metal solution by chemically modified sugarcane bagasse. Bioresource Technology 98(6):1291-1297.

Kunigk L, Santos MCR, Jurkiewicz C (2011) Remoção de íons de cobre de aguardente utilizando carvão ativo e resinas de troca iônica. Acta Scientiarum. Technology 33(1):101-106.

Labanca RA, Glória MBA, Gouveia VJP, Franco Afonso RJC (2006) Determinação dos teores de cobre e grau alcoólico em aguardentes de cana produzidas no Estado de Minas Gerais. Química Nova 29(5):1110-1113.

Lima AJB, Cardoso MG, Guerreiro MC, Pimentel FA (2006) Emprego do carvão ativado para remoção de cobre em cachaça. Química Nova 29(2):247-250.

Miranda MB, Martins NGS, Belluco AES, Hori J, Alcarde AR (2007) Qualidade Química de cachaças e aguardentes. Ciência e Tecnologia de Alimentos 27(4):897-901.

Pandey A, Soccol CR, Nigam P, Soccol VT (2000) Biotechnological potential of agro-industrial residues. I: surgarcane bagasse. Bioresource Technology 74(1):69-80.

Ray D, Sarkar BK, Rana RK, Bose NR (2001) The mechanical properties of vinyester resin matrix composites reinforced wiyth alkali-treated jute fibres. Composites Part A 32(1):119-127.

Santos EG, Alsina OS, Silva LH (2007) Desempenho de biomassas na adsorção de hidrocarbonetos leves em efluentes aquosos. Química Nova 30(2):327-331.

Silva VLMM, Gomes WC, Alsina OLS (2007) Utilização do bagaço de cana-de-açúcar como biomassa adsorvente na adsorção de poluentes orgânicos. Revista Eletrônica de Materiais e Processos 2(1):27-32.

Singh SP, Asthana RK, Singh AP (2007) Prospects of sugarcane milling waste utilization for hydrogen production in India. Energy Policy 35(8):4164-4168. 